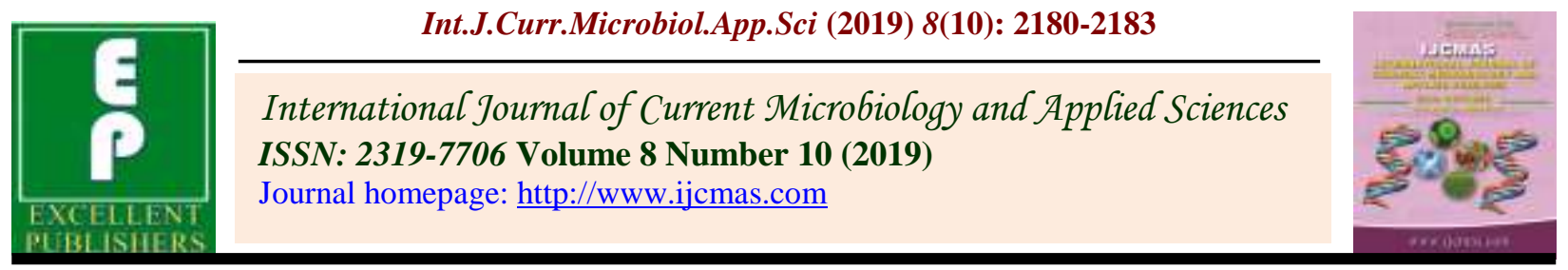

Review Article

https://doi.org/10.20546/ijcmas.2019.810.253

\title{
Assessment of Integrated Pest Management against Onion Maggot in Trans Himalaya Leh
}

\author{
Vikas Gupta $^{1 *}$, Dorjay Namgyal ${ }^{1}$, Anil Kumar ${ }^{2}$, Deldan Namgyal ${ }^{1}$, \\ Sonam Angchuk ${ }^{1}$ and Rigzin Safal ${ }^{1}$ \\ ${ }^{1}$ Krishi Vigyan Kendra-Leh, SKUAST-Kashmir, India \\ ${ }^{2}$ High Mountain Arid Agriculture Research Institute, SKUAST-Kashmir, India \\ *Corresponding author
}

\begin{abstract}
A B S T R A C T
Keywords

Biopesticides,

Insecticides, Cold arid, Onion, Maggot

Article Info

Accepted:

17 September 2019

Available Online:

10 October 2019

Cold arid zone of India lies in the high altitude ranges of north-western Himalayas in the northern most latitudes of the country covering Ladakh province of Jammu and Kashmir and Lahul-Spiti Division of Himachal Pradesh. Ladakh and Lahul-Spiti are well known by the name of cold desert region of India where agriculture season is short only for the summer months of April to September. Most of the insecticides tested under in-vivo conditions were found effective against Delia antique (Onion Maggot) which is serious insect of onion, garlic and other bulbous plants in cold arid region Ladakh. Delia antique, commonly known as the onion fly, is a cosmopolitan pest of crops.
\end{abstract}

\section{Introduction}

Onion (Allium cepa) belongs to the family Liliaceae, an important group of crops worldwide. Onion is grown in temperate, subtropical and tropical climate throughout the world (Brewster JL, 1990; Corgan and Kedar, 1990; Currah and Proctor, 1990). In winter when no fresh vegetables are available in Ladakh region, onion can be taken out of store houses or vegetable sellers for regular consumption or supply to the market (Ganie et al., 2018). Onion maggot, Delia antique (Meagan), is a serious pest of onion and related Allium crops (i.e., garlic and leek) in temperate region throughout the world. It is one of the major constraints for achieving higher production in onion crop in Ladakh region. Onion maggot completes three generations per year in northern region. All three generations can be destructive, but the first generation is the most damaging because it can routinely reduce plant stands by over 50 per cent if crops are not protected. In Ladakh region onion maggot are found in all major onion-growing area which causes severe damage to onion crop (Ajay and Namgyal, 2010). The onion maggot larvae attack germinating seedlings, feeding on the developing roots and epicotyls and can continue to feed on the expanding bulbs during later stages of growth. Eckenrode and 
Walters in 1997 reported that the onion maggot, Delia antique (Meagan) can cause onion stand losses from 20 to 90 per cent in many temperate regions. Onion maggots are highly host-specific to plants in the onion family including onions, leeks, shallots, garlic and chives. Stunted or wilted onion plants are the first signs of onion maggot damage. Light infestations may not kill onion plants but make them more susceptible to bacterial rots.

\section{Situational analysis and problem}

Modern agriculture evolves greater use of technology and has great potential for bringing about socio-economic transformation among the farmers in rural areas. Livelihood options are shrinking in rural areas owing to specific problems and diminishing profitability in agriculture. India is the second largest producer of vegetables next only to China with an area of 7.98 million hectares and production of 129.07 million tonnes. The productivity, however, is quite low compared to many developed countries owing to dependence on traditional cultivation technologies, outbreak of pests and on vagaries of nature.

In hilly state of Jammu and Kashmir in general and district Leh in particular, a significant increase in area under vegetable cultivation has been witnessed during the last two decades. However in recent past biotic stresses especially sucking pests maggot (Delia antique) in onion are becoming major hindrance in production of onion. Onion maggot is a serious pest of onion and related Allium crops in district Leh which cause severe damage to onion crop.

\section{On-farm testing (OFT)}

To address the serious problem of maggot in onion, an OFT was conducted on integrated management of maggot in onion in the micro climatic conditions of the district. On-farm trials comprising four treatments viz. Farmers Practise (No Spray), crop rotation with nonallium crops, dip onion seedlings in chloropyriphos @ 0.2 per cent before transplanting and application of carbofuran3G $1 \mathrm{Kg}$ a.i/ha were conducted by $\mathrm{KVK}$ Leh at 5 locations consecutively for three years during 2015-16 to 2017-18. The results revealed that treatment comprising application of carbofuran $3 \mathrm{G} 1 \mathrm{Kg}$ a.i/ha before transplanting was significantly superior over other treatments and Farmer's practice in terms of pest incidence and onion yield. This treatment resulted in maximum reduction in maggot incidence over control, respectively apart from increase in yield over control (Table 1).

Table.1 Performance of assessed treatments on pest incidence and yield of onion under on-farm trials in district Leh

\begin{tabular}{|c|c|c|c|c|}
\hline Technological options & $\begin{array}{l}\text { Percent reduction over } \\
\text { farmer's practice }\end{array}$ & $\begin{array}{l}\text { Yield } \\
\text { (q/ha) }\end{array}$ & $\begin{array}{l}\text { Net } \\
\text { return }\end{array}$ & $\begin{array}{l}\text { B:C } \\
\text { Ratio }\end{array}$ \\
\hline $\begin{array}{l}\mathrm{T}_{1} \text {-Crop rotation with non- } \\
\text { allium crops }\end{array}$ & 31.66 & 170 & 4000 & 2.00 \\
\hline $\begin{array}{l}\text { T }_{2} \text {-Dip onion seedlings in } \\
\text { chloropyriphos @ }{ }^{0.2} \\
\text { percent } \\
\text { transplanting }\end{array}$ & 58.33 & 200 & 4500 & 2.25 \\
\hline $\begin{array}{l}\mathrm{T}_{3} \text {-Application of carbofuran } \\
\text { 3G } 1 \mathrm{Kg} \text { a.i/ha }\end{array}$ & 74.68 & 220 & 5000 & 2.50 \\
\hline
\end{tabular}




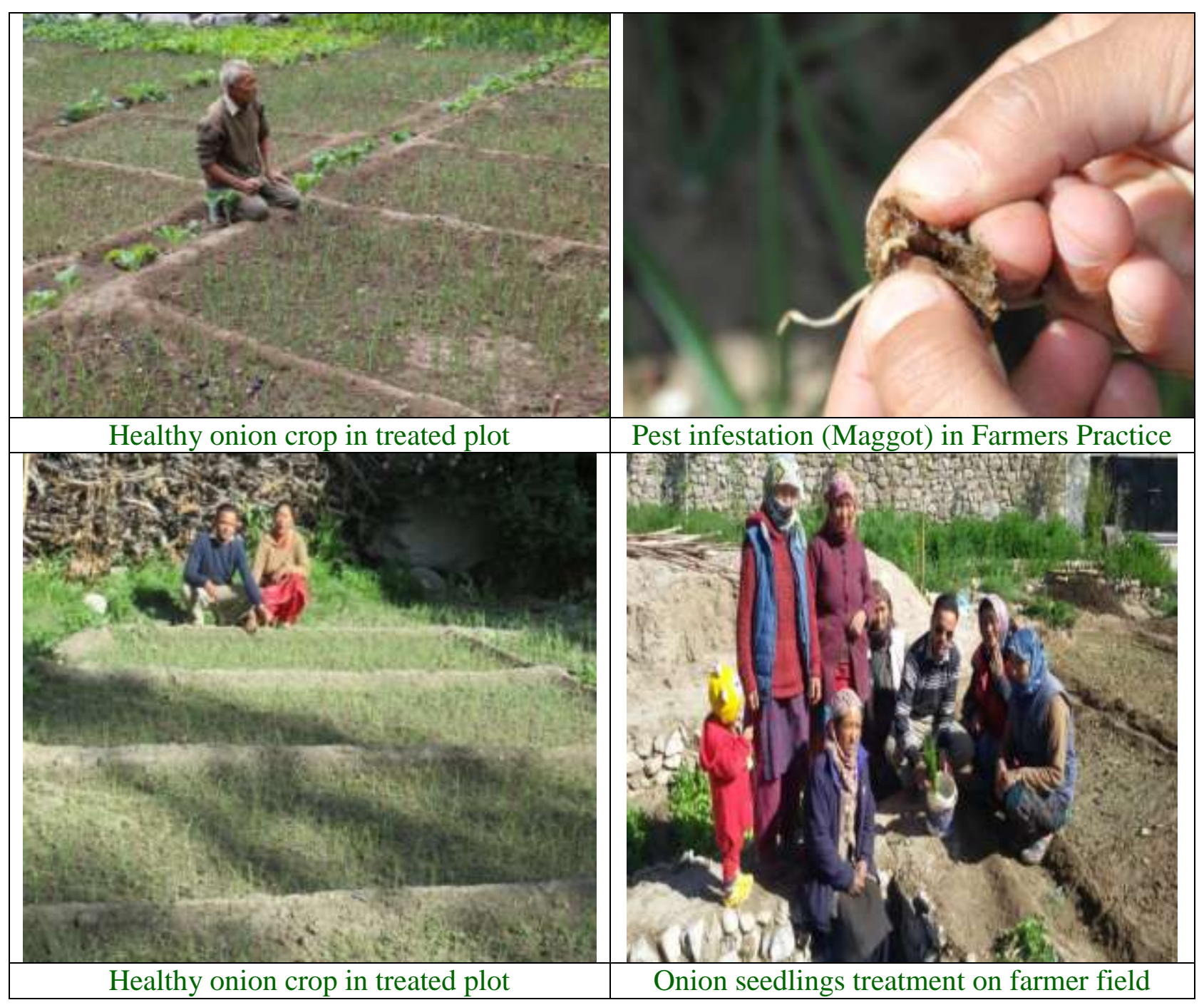

This treatment provided a net return of Rs. 5000 per $100 \mathrm{~m}^{2}$ with $\mathrm{BC}$ ratio of 2.50 followed by other treatments and check.

\section{Up-scaling of technology}

After successful testing under OFTs, the treatment was up-scaled through awareness campaigns and demonstrations for wider application in the district. A total of 10 demonstrations were conducted in different areas of the district. The results revealed that this technology provided maximum higher yields than the farmer's practice. Economic analysis of demonstrated technology in comparison to farmer's practice revealed that on an average, a net additional return of Rs. 5000 per $100 \mathrm{~m}^{2}$ was obtained under the demonstrated technology which was higher than the farmer's practice.

\section{Impact}

The treatment has emerged as a better option for the onion growers of the district. With the initiative of $\mathrm{KVK}$, the technology has spread to about 5 hectare area in the district resulting in additional income to the onion growers in the district. Management of maggot in onion helped in achieving higher yield per unit area and demand of onion fulfilled locally. In view of wider response, this technology has vast 
potential for pest management and could be further intensified effectively in all onion growing areas in the Ladakh Region.

\section{References}

Ajay, K. P, Namgayal, D. Quantification of damage and evaluation of different insecticides against onion maggot, Delia antique in Kargil district of Ladakh region. Journal of Hill Agriculture, 2010; 1 (1): 62-65.

Brewster, J. L. Cultural system and agronomic practices in temperate climates. Onion and allied crops. 1990; 111-31.
Corgan, J. N and Kedar, N. Onion in tropical climate. In: Onion and allied crops. 1990; II: 31-37.

Currah, I and Proctor, F. J. Onion in tropical region. National Research Institute Kent UK. Bulletin No 1990; 35:20.

Ganie, S. A., Wani, B. A., Lone, A. H., Zargar, B. A and Masoodi, T. H. Screening of onion genotypes against purple blotch under cold arid conditions of Ladakh. Journal of Pharmacognosy and Phytochemistry. 2018; 7(6): 27752777.

\section{How to cite this article:}

Vikas Gupta, Dorjay Namgyal, Anil Kumar, Deldan Namgyal, Sonam Angchuk and Rigzin Safal. 2019. Assessment of Integrated Pest Management against Onion Maggot in Trans Himalaya Leh. Int.J.Curr.Microbiol.App.Sci. 8(10): 2180-2183. doi: https://doi.org/10.20546/ijcmas.2019.810.253 